\title{
Texts and tactics: an indirect approach to violence
}

\author{
Stephen Carter
}

Abstract: This essay examines the adaptation of thought forms initially geared toward the management of violence - tactical or strategic paradigms, for instance - as conceptual tools within social and cultural analysis, providing a case study that tracks the instrumental value and attractive power of violence-laden modes of thought. The argument focuses on the early work of Jacques Derrida, placing it into conversation with concurrent military theories of the indirect approach outlined by B. H. Liddell Hart, in order to argue for the presence of martial forms in the paradigm that would become deconstruction, if not more broadly in what Fredric Jameson has called 'the idea of textuality'. The argument establishes the problematic of critical theory and violence, elaborates this intersection through the study of Derrida, and closes by outlining the stakes of the analysis, touching in particular upon contemporary debates around postcritique.

Keywords: Jacques Derrida, B. H. Liddell Hart, deconstruction, indirect approach, military thought, strategy, tactics, textuality, critical theory, postcritique.

Note on the author: Stephen Carter is assistant professor of English at the University of Colorado at Colorado Springs, where he teaches 20th-century American literature and critical theory. His work has appeared or is forthcoming in Criticism, New England Quarterly, boundary 2, War, Literature \& the Arts, and The Canadian Review of American Studies, where it won honourable mention for the 2018 Ernest Redekop prize. He is currently completing a book manuscript that examines the function of military thought within American culture between the Civil War and the long 1960s. 
When, in the course of studying a long series of military campaigns, I first came to perceive the superiority of the indirect approach over the direct approach, I was looking merely for light upon strategy. With deepened reflection, however, I began to realize that the indirect approach had a much wider application. ... The idea of the indirect approach is closely related to all problems of the influence of mind upon mind. Sir Basil Henry Liddell Hart, Strategy (1967 [1991: xx]) In marking out différance, everything is a matter of strategy and risk. ... In the end, it is a strategy without finality. We might call it blind tactics ... Jacques Derrida, 'Différance' (1968: 135)

Long-standing commonplaces regarding violence cast it as a discrete event, a rupture in continuity or aberration from an imagined norm. Scholarship since at least the 1960s has critiqued this conception in two respects. First, it has highlighted the complicity of this framework with certain progressive historical narratives - in a phrase, Whig histories - that position violence as a constitutive outside for modern social life, mobilising what Bernd Hüppauf has labelled the 'relegation' of violence to supposedly extraordinary spaces and times: colonies, frontiers, urban cores, localised epochs of unrest. Second, and in keeping, such criticism has expanded the purview of violence, reframing it as a concept capable of comprehending social structures with durational effects- Johan Galtung's 'structural violence', or the 'slow violence' highlighted by Rob Nixon. ${ }^{1}$ These critiques of the spatial and temporal parameters of conventional conceptions of violence have offered important correctives, though they have also tended, for the most part, to keep other dimensions of the concept intact, not least the framing of violence through, primarily, an ethical lens.

One consequence has been less attention to violence comprehended as a form of knowledge or thought. For present purposes this means less that violence be understood as a meaningful act of communication (violence as dramatic ritual) or that mental acts such as representation and conceptualisation are themselves inherently violent (for instance, speech acts catalysing psychic cum physical harm). Nor does it refer to what James Campbell has called 'combat gnosticism', an ideology in which wartime violence is seen to generate a specific kind of hermetic knowledge accessible only to the initiated soldier. ${ }^{2}$ Rather it is intended to comprehend violence as a set of skills developed through training and education and thus, by extension, violence as practice and concept linked to traditions of thought articulated in professions such as the military. Such a conception, while risky in its departure from frameworks foregrounding the ethical critique of violence, opens the possibility of what Grégoire

${ }^{1}$ Hüppauf (1997: 3, 11), Galtung (1969), Nixon (2011).

${ }^{2}$ On violence as ritual and communication of meaning, see Blok (2001: 105-11). On 'combat gnosticism', see Campbell (1999). 
Chamayou has called a 'technical and political analysis' of violence, a project adopting the technician's viewpoint rather than that of the moralist, with the aim of 'taking apart the mechanism of violence' from, as it were, the inside. ${ }^{3}$

In line with such a conception, this essay examines what happens when thought forms initially geared toward the management of violence-tactical models or strategic paradigms, for instance - are adapted and deployed as cognitive or representational tools within the broader fields of cultural production and social life, that is, in contexts that may at first glance appear removed from violence. Supplementing accounts that focus on violence as itself a problem to be solved, a force to be resisted, or a challenge to be managed - it can be understood as all of these, of course, and much more besides - the essay examines how forms of thought derived from the management of violence have at times been figured as solutions to deeper conceptual problems. In documenting a symbolic investment in concepts and figures derived from milieus such as war and the military, and by conceiving of such frameworks as, in the idiom of Kenneth Burke, 'equipment for living', this paper provides a case study tracking the instrumental value and, hence, attractive power of violence-laden modes of thought. ${ }^{4}$

The essay takes as its particular object of analysis the field of critical theory as it has developed since the 1960s, examining the function of military concepts in shaping still-influential theoretical paradigms of cultural study. By focusing on an early essay by Jacques Derrida, 'Force and Signification' (1963), and placing it into conversation with roughly concurrent military theories of the so-called indirect approach outlined by British tank theorist and grand strategist Sir Basil Henry Liddell Hart, the paper argues for the shaping presence of certain martial forms of thought in the nascent articulation of deconstruction, if not more broadly in what Fredric Jameson has called the 'ideology of the text' or 'the idea of textuality'. Jameson comprehends this as a central aspect of the post-war moment's 'new conceptuality', a translation or transcoding that casts phenomena in a new light and underpins the generative power of the novel discourse of so-called high theory. ${ }^{5}$ As David Couzens Hoy has argued,

\footnotetext{
${ }^{3}$ Chamayou (2015: 15; see also 14-18).

${ }^{4}$ Burke (1973). In comprehending the military sphere as an influential site of modern concept construction, this essay builds on scholarship such as De Landa (1991), Gray (1997), Weber (2005), Der Derian (2009), Bishop \& Phillips (2011).

${ }^{5}$ Jameson (2008a: 21; see also 28, 39-40, 63, 70, 74). Jameson's primary example is Roland Barthes's $S / Z$ (1970), which he uses as an 'individual probe' to open up more general reflections; similarly, this essay outlines one case study as a contribution to attempts "to position "theory" historically and to formulate its status as a discourse' $(21,60)$. To do so is not to discount the advantages of the textual paradigm, not least its critiques of positivism and empiricism and its foregrounding of the discursive construction of categories and concepts, but rather to highlight one moment of critical theory's own concept construction, by way of certain enabling manoeuvres and figures.
} 
this theoretical formation builds upon the hermeneutical tradition and the work of Friedrich Nietzsche: in 'taking the understanding of written texts as a philosophical model', it constructs a particular 'social ontology', a term which Hoy glosses as 'a theoretical model of the salient features of the social configuration'. ${ }^{6}$ A central claim in this essay is that such post-war theoretical mappings of the social field draw from, and build upon, particular martial modes of thought.

Foundational work in this paradigm by Derrida presents itself as a productive case study in the militarisation of critical theory precisely because it is a hard case; given deconstruction's status as a mode of immanent critique particularly attuned to the ethics of representation and interpretation, it is noteworthy that modes of military thought nevertheless do significant conceptual work in this context, shaping conceptions of reading and writing for Derrida. Thus, following but also supplementing work such as Justin Joque's Deconstruction Machines: Writing in the Age of Cyberwar (2018), the argument here contends that, if contemporary war against networked systems involves something like a militarisation of philosophy that 'threatens to turn a deconstructive force against deconstruction by militarising its functioning', then this is perhaps because deconstruction itself had already, in its own terms, been figured by way of martial thought. ${ }^{7}$ The argument first establishes the problematic of critical theory and violence, then elaborates this intersection through the specific case study of Derrida, and, finally, returns to a wider perspective to outline further the stakes of the analysis, in particular as it bears upon contemporary debates around the so-called postcritical turn.

\section{THEORISATION}

In his 'Literacy and the Struggle for Theory' (1994), Wlad Godzich argues that the explosion of critical work in the humanities and social sciences emerging out of the 1960 s, the ascendance and consolidation of so-called theory, is best understood as an extension of the Kantian project of critique. Galvanised by the decade's social upheavals around civil rights, decolonisation, student revolt, and antiwar politics, writers such as Michel Foucault and Derrida, Jean-François Lyotard and Gilles Deleuze, aimed to write 'collectively and dialogically the Critique that Kant never thought of writing: a Critique of Political Reason'. ${ }^{8}$ For Godzich this critical project

\footnotetext{
${ }^{6}$ Hoy $(2004:$ 42, 12; see also 51, 124, 132, 202, 205-6, 212).

${ }^{7}$ Joque (2018: 29; see also 70, 81-2, 86-7, 95, 109, 195-8).

${ }^{8}$ Godzich (1994: 25). On the relationship between theory and the 1960s, see also Herman $(2004: 4-6,12)$, Shumway (2004), Bertram (2004). Cf. Dickstein (2004).
} 
takes the form of a critique of the post-war state form and its ideologies of procedural knowledge and transparency without limit, its dream of 'a society in which nothing will be opaque'. In contrast to this vision, theoretical paradigms grounded in 'the workspace' of textuality and writing highlight the limits of pragmatic and conceptual transparency through the wilful creation of opacity and an ethical focus on the costs of creating such a technocratic society of administrative management, seeking to force a recognition that, despite claims of good intentions and expanding prosperity, such a society 'generates victims'. ${ }^{\text {' }}$

A range of institutional, economic, and intellectual conditions underpinned this theoretical efflorescence, whether reassessments of the legacies of Hegel, Nietzsche, and Edmund Husserl, structural transformations within the post-war university, or the consolidation of a so-called knowledge economy, postmodern image culture, and post-Fordist cum late capitalist modes of production. ${ }^{10}$ Less emphasised has been postwar theory's complex intersection with developments emerging from the military domain; in particular the way the former's collective critique of political reason finds a key enabling condition in its taking up and rearticulating a range of martial imaginaries. ${ }^{11}$ A text like Foucault's Society Must Be Defended may jump most immediately to mind, with its explicit reversal of Carl von Clausewitz's dictum-politics reimagined as war by other means-but consider also Michel de Certeau's tactical overlay of everyday life, the so-called war machine of Deleuze and Félix Guattari, Lyotard's agonistic paradigm of cultural production, or Derrida's recognition, noted in the epigraph above, that the movement of différance tends to generate a textual space defined by 'blind tactics'. ${ }^{12}$ If post-war theory is itself a criticism of Kantian critique - a critique of critique itself, extending its project to political thought - then these critical models encourage a further turn of the screw: a critique of the apparatus of military thought laid bare by the critique of political reason.

\footnotetext{
${ }^{9}$ Godzich (1994: 24, 27-8; see also 21, 24, 32-3).

${ }^{10}$ On theory's critique of Hegel see Godzich (1994: 20-4). For theory's Nietzschean turn, see Hoy (2004: 12-14, 19-56). For theory as extension of Husserl's work, see Hunter (2006: 84-6, 92, 95-100). For the philosophical precursors to theory, see also Lentricchia (1980). On theory and the university, see Cusset (2008: 27-32, 51-3, 59-75, 78-93, 99-106), Newfield (2008: 142-58). See also Graff (2007). For connections between theory and post-war economic shifts, see Jameson (1984: 186-7, 190-201, 206-8). See also Anderson (1983: 40-3). For more detail, see chapters on 'Theory' and 'Economics' in Jameson (1991: 181-278), Denning (2004).

${ }^{11}$ For an exception that links critical theory and modern war, see Dawes $(2005$ : 154-5, 190, 194, 196, 199). See also Carton (2004), Raber (2004).

${ }^{12}$ Foucault (1997: 15-16, 46-51, 159-65, 225-8, 239-40, 257-8), de Certeau (1984: xvii-xx, 35-8, 80-2, 174-6), Deleuze \& Guattari (1986), Lyotard (1985: 9-10, 16-17, 57). See also Hoy (2004: 50, 88), Keenan (1997). Keenan describes Foucault's conception of politics as 'the experience of strategy without finality, pure tactics' (174).
} 
Though such work begins, in this essay, with a local analysis of criticism's own martial imaginaries, it also gestures toward a wider demand for historical and materialist critique of martial thought, articulated by way of the latter's particular conceptual functions within a social totality. Examination of the role of military thought in the work of cultural study enables one to consider whether theoretical lenses aiming to comprehend violence or militarisation within the cultural field have been shaped by the very phenomena they purport to analyse. If critical theory makes use of paradigms of thought derived from domains of violence, then this is significant not least because critical theory as an intellectual tradition is inherently meta- or trans-disciplinary. In what respects have martial modes of thought become an important conceptual means of enabling such capacious projects? To what extent might certain theoretical paradigms reproduce the problem of cultural violence at a higher level, reinforcing such tendencies by reflecting or describing them, rather than subjecting them to analysis and critique?

A decade after Godzich offered one contextualisation of post-war theoretical discourse, Jameson sketched an alternative account that highlighted the "theorising of collective subjectivities' as an emergent moment in the ongoing development of critical theory. ${ }^{13}$ Significantly, he posited this mutation in the theoretical project as developing from the latter's then-nascent engagement with war. If structuralism generated the insight that 'concepts are not ideas but rather words and constellations of words', and so-called poststructuralism transformed this discovery into a philosophical problematic centred on representation, then theory, as Jameson saw it in his own moment of writing, was in the process of turning its gaze to politics, generating a 'genuinely theoretical political theory ... finding its ultimate figure in war' (ST 406). In other words, attention to the discursive roots of concept construction issued into a reexamination of the conceptual foundations of political life, while in turn these revealed their ground in war, inviting focus on the latter as a foundational social imaginary, yet another 'simplification of concrete life in the form of a new model' - what Hoy would call a 'social ontology' (ST 406). Taking up this lineage, the critique of military thought forms practised here performs an internal critical description of conceptual paradigms derived from the martial fold, with the aim of opening space for the articulation of alternative models.

${ }^{13}$ Fredric Jameson (2004), 'Symptoms of Theory or Symptoms for Theory?', Critical Inquiry, 30(2): 403-8. Subsequent citations parenthetical in text, denoted as $S T$. 


\section{DISLOCATION}

Derrida's essay, 'Force and Signification', the piece that opens his first essay collection, Writing and Difference (1978), recommends itself in the present context for two reasons. First, it is one of his earliest published essays, appearing in French in 1963, and hence provides one template for the radical re-evaluation of reading, writing, and critique that would develop under his name during the next half century. ${ }^{14}$ Second, Derrida's work is known for its heightened attunement to the ethical dimensions of reading, the attention it gives to the potentially violent implications of practices of representation and concept formation; as such, it presents an important hard case for any analysis seeking to examine, within critical theory, the work done by forms of thought derived from the violent milieu of war. ${ }^{15}$ The purpose here is not to downplay important critical work around the problematic of representational or conceptual violence. Rather, through a close reading of significant early work aligned with such efforts, a reading performed in a manner that traces Derrida's own approach to explication, the analysis aims both to extend and critique such work by demonstrating precisely the complexity and ambivalence involved in such endeavours.

Derrida's essay takes Jean Rousset's Forme et Signification (1963) as an occasion for examining the historical significance of structuralism. As Derrida argues, however, to describe Rousset's project this way is already to perform a kind of conceptual violence by way of misrecognition. Telling a conventional history of structuralism means repressing the way the latter purports to account for the conditions of possibility that enable this very sort of intellectual work: whatever it is that falls under the name structuralism cannot 'display itself in its entirety as a spectacle for the historian ... the question of the sign is itself more or less, in any event something other, than a sign of the times ... structuralism escapes the classical history of ideas which already supposes structuralism's possibility'. To historicise structuralism is thus, according to Derrida, to disregard a central aspect of its significance: 'The structuralist stance, as well as our own attitudes assumed before or within language, are not only moments of history. They are an astonishment rather, by language as the origin of history.

\footnotetext{
${ }^{14}$ 'Force and Signification' appeared in print first (July 1963), but was preceded by two lectures: “ "Genesis and Structure" and Phenomenology' (delivered 1959) and 'Cogito and the History of Madness' (delivered March 1963), both of which appeared in print in 1964.

${ }^{15}$ See, for example, Derrida (1976: 101, 110, 112, 127, 135-40). For a more general take on the centrality of ethics for Derrida's project, in particular via his engagement with the work of Emmanuel Levinas, see Hoy (2004: 149, 152, 163-4, 171, 174-5, 178, 181-4). Hoy argues that Levinas's model, and by extension that of Derrida, is explicitly pitched against a philosophical tradition, for instance Hobbes and Hegel, that imagines social life as violent struggle or war $(155,158-61)$. See also Joque $(2018$ : 92, 189).
} 
By historicity itself.' ${ }^{16}$ Rather than treat structuralism symptomatically, as a 'sign of the times', Derrida, in a critical move forecasting subsequent work, casts it as a distillation of a long-standing pattern, the 'system of metaphysical oppositions' that underpins the history of Western thought. If structuralism reveals in stark form the basic DNA that defines metaphysics as a system, then it also presents, in this very achievement, a point at which that system's vulnerabilities are made visible. Exploiting this opening, Derrida's approach takes the form of immanent critique, working through structuralism to emerge from the other side, aiming 'to seek new concepts and new models, an economy of escaping this system of metaphysical oppositions' (FS 19).

Derrida inaugurates this critical work through numerous tropes that draw from martial or violent imagery, speaking first of 'the structuralist invasion', and then describing the contrary historicising gesture in comparable terms: 'To dream of reducing it [structuralism] to a sign of the times is to dream of violence' (FS 3). For Derrida this field of reductive, invasive, violent theoretical manoeuvres characterises the foundation of structuralist thought itself, for the focus on structures signals, perhaps counter-intuitively, attention to the possibility of their collapse: 'Structure is perceived through the incidence of menace, at the moment when imminent danger concentrates our vision on the keystone of an institution, the stone which encapsulates both the possibility and the fragility of its existence' (FS 6). Derrida's figuration of 'structure' locates it within a wider field of 'menace' and 'imminent danger', for attending to structures derives from a concern with their endurance, and hence with potential catastrophes that might lay them waste.

In keeping with these topoi of 'invasion' and 'violence', 'menace' and 'danger', Derrida's critique of structuralism is enabled by, and revolves around, a figure borrowed from the military sphere: that of strategy. Through this figure, the essay elaborates an alternative spatial imaginary to that of structure, one which-interestingly, given the term's martial resonance - appears to imply the possibility of escape from the aggressive and violent imaginaries that, according to Derrida, underpin both structuralism and historicism. For Derrida, the specific critical manoeuvre, what he calls a 'certain organization', that would 'dislocate' the structure of binary opposition is understood as 'strategic':

Our discourse irreducibly belongs to the system of metaphysical oppositions. The break with this structure of belonging can be announced only through a certain organization, a certain strategic arrangement which, within the field of metaphysical

\footnotetext{
${ }^{16}$ Jacques Derrida (1978), 'Force and Signification', in Writing and Difference, trans. Alan Bass (Chicago, IL, University of Chicago Press: 3-30), see pages 3, 4. Subsequent citations parenthetical in text, denoted as $F S$. All emphases in the original. Focused on another early essay by Derrida, Ian Hunter also addresses Derrida's resistance to telling a history of theory (2006: 81-7). Cf. Jameson (2008b).
} 
opposition, uses the strengths of the field to turn its own stratagems against it, producing a force of dislocation that spreads itself throughout the entire system, fissuring it in every direction and thoroughly delimiting it (FS 20).

If Derrida figures the spatial imaginary of structuralism in sited, architectural terms'the architecture of an uninhabited or deserted city', with structure implying location: four walls, city limits, territorial boundaries (FS 5) - then the introduction of a 'certain strategic arrangement' into the structuralist frame generates 'a force of dislocation that spreads itself throughout the entire system, fissuring it in every direction and thoroughly delimiting it'. Structuralism's site is thus enveloped and situated within a wider field of strategic movement, revealing a 'strategic operation ... which cannot simply be conceived under the authority of structuralism' (FS 28). To upend structuralism one must think strategically rather than structurally.

It might be argued that the figure of strategy is not distinctively martial; after all, it is common to speak of business strategy, social media strategy, gametime strategy, or career strategy, if not, more generally, to use the word as a synonym for planning, even for intentional action itself. This is not the place for a broader account of the concept's historical development, which would include its etymological derivation from the Greek stratos (army) and codification as an object of sustained theoretical inquiry in professionalising Western military milieus after the Napoleonic Wars. ${ }^{17}$ Nor is there space here for deeper reflection on the way such turns of phrase have become commonplace - tending to congeal into normalised conceptual reframings of everyday activities - primarily in tandem with the development of market-based social life, the constitutive systemic premise of which is agonistic competition among adversaries.

For present purposes a more local concomitance will suffice - that is, a striking aspect of Derrida's deployment of a 'strategic' trope is the extent to which this

\footnotetext{
${ }^{17}$ The term derives from the Greek compound of stratos (army) and agein (to drive or lead). The former refers specifically to an encamped army, while the ag root implies both critical judgment, as in cogitate, and directed action, as in protagonist and agenda. See Partridge (1959: 9, 673-5), Shipley (1984: 3). It is not until the late 18th century, in the writings of the French lieutenant-colonel Paul Gideon Joly de Maizeroy, that strategy emerges as an object of consistent military inquiry in the West. Subsequently, after the Napoleonic Wars, the Swiss writer Antoine Henri de Jomini isolated strategy as a conceptual object and designated it as the elevated content of martial knowledge, at the very moment when the professionalisation of military affairs was gathering steam in Europe. The study of strategy thus became a central part of the curriculum at a range of newly minted staff colleges, providing an abiding portion of the intellectual content undergirding the differentiation of the military sphere in its post-Enlightenment form. On these developments see Gat (2001: 43-5, 73-5, 82-5, 96, 112-15), Shy (1986: 144). On the creation of staff colleges, see Keegan \& Holmes (1986: 214-16). Prior to this moment the differentiation of the military had been articulated primarily in class terms. See Vagts (1959: 168, 294-7), Keegan (1988: $4-5,177-81)$.
} 
particular 'strategy' echoes the roughly concurrent military paradigm of British tank theorist and grand strategist Sir Basil Henry Liddell Hart: the so-called indirect approach, developed first during the interwar period, and then elaborated over the next four decades. Compare Derrida's notion of a strategy that 'uses the strengths of the field to turn its own stratagems against it' with Liddell Hart's gloss, in his Strategy (1967), of the battle of Cannae, in which Hannibal turned the strengths of the Roman army against it, enveloping the structures of the Roman legions within a wider strategic field:

As was customary, the infantry of both sides were posed in the centre, and the cavalry on the flanks-but Hannibal's detailed disposition was unconventional. For he pushed forward the Gauls and Spaniards, who formed the centre of the infantry line, while holding back his African foot, posted at the end of each line. In that way the Gauls and the Spaniards formed a natural magnet for the Roman infantry, and were, as intended, forced back - so that what had been a line bulging outwards became a line sagging inwards. The Roman legionaries, flushed with their apparent success, crowded into the opening - where the press grew ever denser, until they could scarcely use their weapons. While they imagined that they were breaking the Carthaginian front, they were actually pushing themselves into a Carthaginian sack. For at this juncture, Hannibal's African veterans wheeled inwards from both sides, enveloping the thickly packed Romans. ... This situation produced ... a trap. ... It might aptly be termed a tactical form of ju-jitsu, which is essentially based on the indirect approach. ${ }^{18}$

In light of this comparison, Derrida's announcement of a mode of critical practice can be seen as a sort of textual or critical Cannae. Derrida's essay not only twists away from the 'structure of belonging' that is Western thought by way of a 'certain strategic arrangement', but also does so via a certain - that is, specific and particular - strategic arrangement: the indirect approach, which undermines the solidity of the structured site by comprehending it within a more expansive strategic field. This can be seen also in Liddell Hart's example of Belisarius, a Byzantine general who, for Liddell Hart, exemplifies 'the essential characteristic of the indirect approach - that of getting an opponent off balance, so that a joint becomes exposed and can be dislocated' ( $S$ 52). So too does Derridian explication proceed by the dislocation of certain 'joints' in the open textual field, junctures around which the pressure of reading is gathered until the joint collapses and becomes a hinge for leveraging and upending the structured apparatus - 'as in ju-jitsu, his own effort is turned into the lever of his overthrow' (S 146). ${ }^{19}$

${ }^{18}$ Liddell Hart, Basil Henry (1967), Strategy, 2nd revised edn (New York, Meridian), 28-9. Subsequent citations parenthetical in text, denoted as $S$. See also Hoy (2004: 83-5).

${ }^{19}$ See, for instance, Derrida (1976: 65-73, 1994: 17-20). See also Joque (2018: 75-6). 
Liddell Hart developed his paradigm first during the 1920s and 1930s in the tactical context of mobilised tank warfare, and then articulated a more expansive vision between the 1940s and 1960s. His work not only shaped Cold War doctrines of containment and deterrence, but has also informed post-Cold War liberal-democratic theories of war, from sanctions and joint-strike formations to so-called precision warfare. ${ }^{20}$ The core of Liddell Hart's interwar re-evaluation of strategic thought resides in its critique of the 'decisive battle' that had defined military theory since Clausewitz- 'historically', as one historian glosses Liddell Hart, "the concept of "victory" proved to be a ruinous but persistent delusion' - in order to emphasise instead 'oblique' strategies of 'dislocation' in assuring military success: as Liddell Hart puts it, 'In most campaigns the dislocation of the enemy's psychological and physical balance has been the vital prelude to a successful attempt at his overthrow' $\left(S\right.$ 6). ${ }^{21}$ If an approach grounded in decisive confrontation focused on the annihilation of the enemy's armed forces, then the indirect approach emphasises a wider conception of strategic ends, reinscribing such destruction within a more expansive paradigm that aims at dispersal and disintegration. The target of combat becomes the enemy's will to fight - morale, or psychological resources - rather than concrete manifestations of that will.

Liddell Hart's repeated emphasis on the act of 'dislocation' is significant not only for its resonance with Derrida's own use of this term, but also, more importantly, because it gestures toward the way that, in addition to dislocation on the operational plane, Liddell Hart dislocates both the space of war and the category of strategy itself - to borrow language from Derrida, his work 'fissures' and 'delimits' the two in tandem. By shifting primary attention to the broader logistical and psychological conditions that make 'strategy' in a more narrow sense possible - the 'vital prelude' to battle itself - Liddell Hart's paradigm of the indirect approach destabilises the very category of which it purports to be an example. Liddell Hart's critique issues into a dedifferentiation of tactics, strategy, and politics, engendering conceptual slippage among these planes. In turn, one consequence of this vision is that the contained imaginary of a structured field - the supposed site of decisive battles - gives way to the fluid and dynamic operational volume of what, in contemporary parlance, has come to be called 'battlespace', a flexible and porous setting for violence, with inherently unstable spatial and temporal boundaries. ${ }^{22}$ This context is important because it

\footnotetext{
${ }^{20}$ On the development of Hart's theories, see Gat (2001: 664-80, 703-19, 736-9, 751-61, 765, 772-5, 806-16, 820-3, 826-8). For contemporary echoes, see Chamayou (2015: 62, 127), Joque (2018: 3).

${ }^{21}$ Gat (2001: 795; see also 682, 694, 800, 803). See also Liddell Hart (1967: 14, 16, 22).

${ }^{22}$ On the metamorphosis of war's spatial and temporal coordinates, see Lindqvist (2000: 50, 68, 71, 81, 83-4, 123, 184), Hardt \& Negri (2004: 51-62), Blackmore (2005: 5, 38-9, 53, 128, 133), Davis (2008: 4-12, 116-29, 162-4, 188-91), Graham (2009: 279-81), Gregory (2011: 238-42), Chamayou (2015: 32, 42, 48, 52-9, 114-24), DeRosa \& Peebles (2017: 207-13), Joque (2018: 24-7, 35-8, 42-3, 45-9, 55-8, 63-6).
} 
indicates that Liddell Hart's vision is not necessarily less 'violent' than a 'direct' focus on decisive confrontation; indeed, it may escalate violence in tending toward a decontainment of war, as for instance in William Sherman's so-called march-to-the-sea during the US Civil War, which Liddell Hart cites as an example of the strategy of the 'indirect' approach, or the targetting of civilian morale through aerial bombing of urban centres ( $S 125-6,131-6) .{ }^{23}$ Complicating matters further is the way that, because Liddell Hart's paradigm critiques an imaginary of war that corresponds most clearly with conventional notions of violence as ruptural moment and discrete event, it also tends to occlude its own status as merely a reframing of violence, rather than an alternative to it.

As in Liddell Hart, so too in Derrida the site of decisive judgment is distended and dislocated, incorporated within a more expansive matrix. For the binary opposition as model of containment, Derrida's essay substitutes the open field of the text, which is described, in a phrase that recalls Liddell Hart, as encompassing the 'richness implied by the volume', an operational space within which meaning is defined not through the fixity of interpretation, but by 'infinite implication, the indefinite referral of signifier to signifier ... pure and infinite equivocality which gives signified meaning no respite, no rest' $(F S 25){ }^{24}$ Though it is certainly the case that the dissolution of the sites of Western metaphysics, from structuralism's neat oppositions to new criticism's organic wholes, promises liberation of a sort, it is equally important, given the overlaps sketched here, to attend carefully to the apparently unstructured imaginary that replaces them. The point is not to generate nostalgia for metaphysics or structuralism, but rather to pose the questions that Derrida's own figures invite: What sort of imaginary is used to comprehend these dismantled structures and fissured spaces? In what respects is this novel construct actually quite specifically structured - that is, by way of a militarised 'arrangement', a 'certain strategic' orientation to, and within, the cultural field? To the extent that these martial figures facilitate a determinate negation of metaphysics - by designating that 'which cannot simply be conceived' within the latter- they encourage, following Derrida's lead, an immanent critique of these enabling conditions: a critique of martial tropes at work within the critique of metaphysics.

\footnotetext{
${ }^{23}$ See also Gat (2001: 684).

${ }^{24}$ On this textual model used to comprehend cybernetic war, see Joque (2018: 20, 59-63). Joque argues that deconstruction involves an essential 'lack of a fixed structure' (102); this is perhaps true, but that does not mean that it does not create new, dynamic structures, such as that of text-as-battlespace. Hoy argues that deconstruction revolves around a general critique of the capacity to make conceptual distinctions (2004: 177).
} 


\section{FIGURATION}

Two objections might be brought against this line of interpretation, each of which needs to be addressed before taking leave of Derrida's essay. First, critics might protest that this analysis places inordinate weight on what is ultimately an elaborate conceit, which merely lends an image to the argument through which Derrida upends the paradigm of structuralism. While this strikes a useful cautionary note, close attention to the figural aspect of the text is quite in line with Derrida's treatment of structuralism. Not only, as other critics have argued, is attending to figuration an integral part of the mode of textual commentary associated with Derrida's name, but in this specific essay Derrida explicitly anticipates a similar objection to his own commentary on Rousset. ${ }^{25}$ Speaking of the 'geometric or morphological elements' of Rousset's text, Derrida remarks: 'This geometry is only metaphorical, it will be said. Certainly. But metaphor is never innocent. It orients research and fixes results. When the spatial model is hit upon, when it functions, critical reflection rests within it. In fact, and even if criticism does not admit this to be so' (FS 17). Derrida's comment highlights the importance of pinpointing the metaphors that orient research by providing it with models and thought forms. By this same token, just as geometric models inform structuralism, so too 'critical reflection rests within' Derrida's recourse to the figure of strategy, for this provides a significant thread 'orienting' the Derridian critique of the fixed sites of structuralism's geometric models. ${ }^{26}$

With this attention to figuration in mind, the passage outlining a 'certain strategic arrangement' actually gains deeper significance: the explicit use of a trope to pivot away from structuralism signals the wider role of tropes within Derrida's redefinition of reading and writing, which is of a piece with his critique of metaphysical thought. For Derrida, figuration is exemplary of the paradigm he offers as an alternative model to the fixity of structuralist reading. As Derrida puts it, the working of metaphor eschews stasis (encompassing 'everything in language except the verb to be'), which allows him to define practices of reading and writing as constant translations across texts and contexts, a continual movement without firm location, in which unforeseen transformations necessarily occur (FS 7). For Derrida, all meaning is approximate and negotiated, differing and deferring depending on context, as captured in his neologism, différance; figuration just makes this explicit, and hence is central to

\footnotetext{
${ }^{25}$ On the status of figuration in deconstruction, see Harvey (1988: 254, 264), Garver (1979: xi-xiv, xxii, xxvi). Derrida himself treats the problematic of figuration within Western thought in 'White Mythology: Metaphor in the Text of Western Philosophy' (1982). Though there is a difference between 'figure' and 'trope' in classical and medieval rhetoric, this essay, like much work in post-war critical theory, uses the two interchangeably. On this point, see Paxson (2003: 72, 91n14).
}

${ }^{26}$ See also Felski (2015: 52). 
redefining 'writing as metaphoricity itself', as he puts it in Of Grammatology ${ }^{27}$ In this light, the trope of strategy operates both as an instance of figural thought that renders, in a specific way, the operational field unfolding as inherited structures dissolve, and also as an announcement of the role that figuration itself will play in this dissolution. The martial metaphor signifies on two levels: in terms of its signified content- the 'certain organization' implied - and as a statement about the significance for Derrida's project of the wider category of figuration or rhetoric.

Second, it might be objected that the specific figure of strategy is best treated as one figure among others; though it may be conceded that Derrida privileges it in this early essay, his later work also makes use of other figures and tropes to describe the paradigm of textuality and the work of figuration..$^{28}$ In other words, to what extent is there a distinctive relationship between the deployment of a particular set of figures derived from the martial sphere, and an understanding of the field of figuration itself? On one level, there need be, of course, no inherent connection between the twothough it is worth noting in this context the long-standing practice of comprehending rhetoric by way of combat..$^{29}$ On another level, it may be that the martial figure, once established, is difficult to dislodge. If an exemplary mode of figuring the elaboration of a set of tropes is to understand it through a martial idiom, then this is the case, perhaps, because the movement of figuration opened by this designation can itself be comprehended by way of that very militarised frame. To employ Derridian diction, the martial figure of 'strategic arrangement' differs and defers, like all figures, but with the difference that this very movement is in turn re-enveloped within a dynamic field of strategico-textual manoeuvres among readers and writers across ever-shifting contextual terrains - while the latter image of the text as space of manoeuvre can, simultaneously, be grasped as a figure. The martial idiom, in the form of the strategy of the indirect approach, does not purport to fix the unfolding of meaning-to operate as master signified or metalanguage - for its articulation operates immanent to the very practices of reading and writing, analysis and critique: far from stemming such unfolding through decisive victory, it operates as an exemplary figure for this apparently ceaseless, dislocated manoeuvring itself. A textual analysis - such as the one offered here - that works to upend the strategic figure, by treating it as a significant

\footnotetext{
${ }^{27}$ Derrida (1976: 15).

${ }^{28}$ Examples include economic circulation, libraries, parergonality and ornamentation, parasitism, supplements and prostheses, textiles and weaving, haunting and spectrality, justice, and autoimmunity. See the following by Derrida: Writing and Difference (1978: 270-3), 'The Purveyor of Truth' (1988: 180, 184, 198-9, 204), Of Grammatology (1976: 54), Specters of Marx (1994: passim), 'Force of Law: The "Mystical Foundation of Authority"' (1992: 14-15, 25, 63-4). See also Joque (2018: 77-9, 135-6, 153-7, 158, 164-5, 180).

${ }^{29}$ See de Certeau (1984: 39-42, 78, 100), Moretti (1988: 3-9, 24-7).
} 
textual joint through which a field of figures itself might be brought into focus, also enables the latter's proliferation. Interimplicated, martial field explicates figural field, and vice versa. ${ }^{30}$

It is thus not insignificant that this early announcement by Derrida of the central importance to be accorded the dislocating operations of figuration, and the representation of the textual field opened by this move, are condensed in one and the same figure: that of strategy. Through its deployment of the strategic figure at this pivotal juncture, Derrida's text establishes, without fully examining, a certain affinity between figural field and battlefield, implying that the volume of the text is aptly grasped in a martial idiom, as essentially a strategic field defined by the indirect approach: 'a certain organization ... a certain strategic arrangement'. This is a foundational metaphor that orients reading and writing - the practice of analysis, the paradigm of textuality - in this early essay by Derrida. ${ }^{31}$ As the organisational models of Western metaphysics dissolve, they leave in their wake a disjointed field within which particular military modes of thought provide strikingly effective paradigms of orientation.

\section{DEMOBILISATION}

What is illuminated by returning, in the present moment, to an early essay by Derrida? Even as his essay offers an important initial articulation of what would become deconstruction, the significance of which within post-war culture might be assumed to speak for itself, it could also be claimed that the moment for so-called high theory has passed, and that alternative approaches and methods - digital humanities, new materialism, models derived from cognitive engineering - are now having their time in the sun. Indeed, recently the project of critical theory has itself become an object of critique, cast by some as limiting if not counterproductive. Writers from varied quarters have called for work grounded in concern and repair rather suspicion, or for reading practices attending to the surface of texts rather than modelling a purportedly invasive quest for meanings in depth. For present purposes a significant aspect of such criticism - currently assembled under the shorthand, postcritique - concerns the collective charge that the sort of project exemplified by work such as that of Derrida is steeped in, and encourages, attitudes that are aggressive, antagonistic, and

\footnotetext{
${ }^{30}$ The relationship between figuration as such and martial figures in particular might be understood as an example of what Harold Bloom calls 'transumption' or 'metalepsis', a trope that tropes on troping (see 1975: 47, 74, 88-90, 178, 1982: 119-37, 195).

${ }^{31}$ On this textual battlespace of manoeuvres, feints, and ruses, see also Jameson (1991: 391-9, 1999: 31-3), Felski (2015: 83, 110-12, 188).
} 
combative - in a word, violent. ${ }^{32}$ There is substantial irony to this depiction, for, as indicated, central threads of critical theory are defined precisely by their careful attunement to the violence inherent in certain modes of representation and concept formation. Critics who label critical theory violent thus assert not only that it can be judged wanting by an absolute ethical standard that condemns violence in the abstract, but also, more trenchantly, that it reinforces the very tendencies it claims to resist. ${ }^{33}$

The foregoing analysis of Derrida suggests that there is something to such an assessment. Certain strands of critical theory articulate and deploy models derived from the violence-laden milieus of military thought. To the extent that such paradigms remain undertheorised - that is, when they become imaginaries that imply social ontologies and enable descriptive acts, without themselves becoming subject to analytic scrutiny - it can be argued that the project of critique generates a kind of second-order representational or conceptual violence, and this despite its own explicit attempts to mitigate the latter in other respects. In turn, if such work makes use of forms of thought derived from domains of violence, then this is significant in a further respect because, as noted, critical theory as an intellectual project aims to cross-cut and integrate disparate knowledge fields, whether through critiquing the partial vision of specific disciplinary formations, or articulating horizontal linkages among them. In this light it is possible to see martial thought as providing a generative but fraught reservoir of meta-analytic forms, what Chris Hables Gray calls a 'metadiscourse', that, like military-derived logistical networks in the world market, enable

\footnotetext{
${ }^{32}$ For instance, in an important early touch point in this trend criticising critique, Eve Kosofsky Sedgwick advocates reading as repair rather than suspicion. See Kosofsky Sedgwick (1997). For a more recent statement see Felski (2015: 55, 64-5). Felski consistently describes critique with words such as 'militant,' 'vigilance', 'wariness', and 'adversarial' (1, 2-3, 10, 17, 20, 37, 76, 86, 106, 142), arguing that it operates in a 'combative idiom' (23), or 'like a weapon' (120) that 'highlights the sphere of the agon' (17); she compares critique to a detective hunting a criminal (7, 46, 85-107). For further discussion of these ideas see also the essays collected in response to Felski's book: PMLA, 132(2) (March 2017): 331-91. For an earlier articulation of the term 'postcritique', where it carries a different valence, see Hoy (2004: 17-18, 93, 148, 190).

${ }^{33}$ On critical theory's attunement to the violence of interpretation, see Hoy $(2004: 33,48,50,55,94,130)$. Cf. Felski $(2015:$ 106, 114, 190). The irony is deepened when Felski describes her own turn to a more generous interpretive mode as a 'change in tactic' (107), or when one considers Bruno Latour's explicit use of martial imagery in his essay, 'Why Has Critique Run Out of Steam? From Matters of Fact to Matters of Concern' (Latour 2004), often cited, along with Sedgwick, as an early moment of postcritique. At times Latour's figures seem intended as an ironic dig at critical theory, casting it as irretrievably bound up with the militarised 'metaphorical atmosphere of the time', rife with 'So many wars', while in the same breath 'military experts', who 'constantly revise their strategic doctrines', appear as models for scholarly scruples and circumspection (2004: 225; see also 226-32,242). From the perspective taken in this essay, it is a curiously ambivalent rhetorical performance, which itself suggests the complex imbrication of high theory, the project of critique, and martial modes of thought. On Latour's martial rhetoric, cf. Love (2017: 50-1, 54, 60).
} 
transdisciplinary work by hinging together a conception of the social whole in a certain, militarised manner. ${ }^{34}$

At the same time, while acknowledging this line of insight, the analysis here parts ways with so-called postcritique in that its aim is not to sideline or transcend the project of critical theory. Though a useful corrective in some respects, much work along postcritical lines appears, in this writer's view, to misapprehend its own image of critique, cast as an attitude or set of abstract values (suspicion, paranoia, antagonism), as an adequate conceptualisation derived from a genealogy of the historico-epistemological project of critical theory, running from Kant through Marx and beyond. ${ }^{35}$ Even granting for the moment certain aspects of postcritique's image of critical thought, a question persists: Is the most productive response to abandon it in favour of an alternative set of values such as repair, concern, generosity, or attachment - all positive motivations, but all just as abstract as suspicion or paranoia-or instead to develop alternatives that emerge from a concrete internal analysis of specific conceptual knots and institutional impasses that have themselves contributed to the current reification of the critical project?

The question gestures toward two concluding points. On the one hand, it echoes a distinction raised in this essay's opening: a bifurcation between an external, ethical critique of violence, in the name of laudable but nevertheless abstract values, and Chamayou's call for a technician's perspective that would analyse the internal 'mechanism' of violence at work in the grooves and manoeuvres of critical thought itself. In subscribing to the latter project, the work here aligns not only with Chamayou, but also with Marx's own sense of the goals of critical work, as articulated in his 1843 letter to Arnold Ruge: 'The reform of consciousness consists solely in letting the world perceive its own consciousness by awaking it from dreaming about itself, in explaining

\footnotetext{
${ }^{34}$ Gray (1997: 99). On the central role of military thought forms such as operations research and cybernetics in mapping the post-war global social and economic field, see De Landa (1991: 5, 82-3, 111-12), Gray (1997: 139-49), Bishop \& Phillips (2011: 15-16, 117-18, 125-9, 132).

${ }^{35}$ Christopher Castiglia labels such reductions 'caricatures ... neither full nor fair', describing them as forms of 'critiquiness', offering the 'sound of critique', rather than critique itself (2017: 211, 214). See, for instance, Latour 'Why Has Critique', which reduces critique to a cynical defence mechanism against being duped (2004: 237-41). For an essay attuned to matters of concern, the piece shows very little concern to depict critique accurately; perhaps this is because Latour casts critique as an unfair adversarynot unlike a 'terrorist' (243) - and so judges that it need not summon such concern. Felski 'renames' or 'redescribes' critique as a 'widespread sensibility' or 'shape of thought' practised by an imagined 'expert reader', primarily the product of contemporary graduate education in the humanities (2015: 2, 39). A similar flattening of the critical project can be seen when Stephen Best and Sharon Marcus, in their survey of the field of criticism, quickly reduce 'interpretation' to 'Marxism', then to 'symptomatic reading', and finally to the work of Fredric Jameson (2009: 1-6). On Jameson as the bugbear of postcritique see also Anker \& Felski (2017: 5-7). For an alternative genealogy of the critical project, highlighting its conservative roots, cf. During (2017).
} 
to it its own actions. ${ }^{36}$ If critical theory's critique of political reason has, at least in part, run aground on its own deployment of martial thought, then to examine the latter is to bring one aspect of critique's own enabling dream consciousness into the light of day.

On the other hand, and finally, if this latter path sets out to chart critical theory's own immanent critique, and hence cannot but work with raw materials embedded in this inherited tradition, then it also commits itself to working through questions of how to repurpose a conceptual apparatus generated in part through certain functional linkages to milieus of coercion and violence. Framed in this way, the problematic extends well beyond the field of post-war critical theory to encompass broader conceptual legacies of militarisation, not least within the institution of the university itself. Confronted with long-standing and ongoing sedimentation of war in intellectual life, the challenge might be imagined as akin to carrying out, across a range of knowledge fields and institutional contexts, a conceptual counterpart to processes of economic reconversion and social demobilisation in the aftermath of wartime production, all with the aim of developing forms and models that, to borrow words from Alberto Toscano, 'would finally escape the paradigm of war'. ${ }^{37}$ Indeed, in the face of rhetoric lauding supposed all-volunteer armed forces and so-called revolutions in military affairs, a central significance of post-war critical theory may turn out to revolve around its status as an emblematic reminder that social life following the Second World War has never truly been demobilised..$^{38}$ This historical horizon indicates that any project aiming at the reconversion of intellectual work, motivated by a desire to articulate human intelligence beyond agonistic life, is unlikely to succeed if not accompanied by sustained material commitment to demobilisation in actual fact.

Acknowledgements: Thank you to the American Philosophical Society, the British Academy, and the American Academy of Arts and Letters, for their February 2018 workshop on violence, in which this material took shape.

\footnotetext{
${ }^{36}$ McLellan (2000: 45). On the letter to Ruge, see also McLellan (1970: 126-8), Butler (2006). For other takes on critique as a project attuned to structures of consciousness and processes of knowledge production, see, for instance, Foucault (2002), Guillory (2002: 20-4), Chandler (2004).

${ }^{37}$ Toscano (2007: 191). For possible models of such work, one might consider Rey Chow's rethinking of area studies through the notion of the target, or Fredric Jameson's recent argument for an army without war as socialist paradigm. See Chow (2006), Jameson (2016).

${ }^{38}$ On this point, see Castiglia (2017: 215-16). On the challenges of reconversion and political battles around demobilisation after the Second World War, see Koistinen (2004: 130-2, 275-82, 446-94, 500-16).
} 


\section{REFERENCES}

Anderson, Perry (1983), In the Tracks of Historical Materialism, The Wellek Library Lectures (London, Verso).

Anker, Elizabeth S. \& Felski, Rita (2017), 'Introduction', in Elizabeth S. Anker \& Rita Felski (eds) Critique and Postcritique (Durham, Duke University Press), 1-30. https://doi.org/10.1215/9780822373049

Barthes, Roland (1970), S/Z (Paris, Seuil).

Bertram, Benjamin (2004), 'The Spectrality of the Sixties', in Peter C. Herman (ed.) Historicizing Theory (Albany, NY, State University of New York Press), 277-99.

Best, Stephen \& Marcus, Sharon (2009), 'Surface Reading: An Introduction', Representations, 108(1): 1-21. https://doi.org/10.1525/rep.2009.108.1.1

Bishop, Ryan \& Phillips, John (2011), Modernist Avant-garde Aesthetics and Contemporary Military Technology: Technicities of Perception (Edinburgh, Edinburgh University Press).

Blackmore, Tim (2005), War X: Human Extensions in Battlespace (Toronto, University of Toronto Press).

Blok, Anton (2001), Honour and Violence (Malden, MA, Blackwell).

Bloom, Harold (1975), Map of Misreading (Oxford, Oxford University Press).

Bloom, Harold (1982), Agon: Towards a Theory of Revisionism (Oxford, Oxford University Press).

Burke, Kenneth (1973), 'Literature as Equipment for Living', in The Philosophy of Literary Form (Berkeley, CA, University of California Press), 293-304.

Butler, Judith (2006), " "Philosophy Has Become Worldly": Marx on Ruthless Critique', PMLA, 131(2): 460-8. https://doi.org/10.1632/pmla.2016.131.2.460

Campbell, James (1999), 'Combat Gnosticism: The Ideology of First World War Poetry Criticism', New Literary History, 30(1): 203-15. https://doi.org/10.1353/nlh.1999.0002

Carton, Evan, (2004), 'The Holocaust, French Poststructuralism, the American Literary Academy, and Jewish Identity Politics', in Peter C. Herman (ed.) Historicizing Theory (Albany, NY, State University of New York Press), 17-47.

Castiglia, Christopher (2017), 'Hope for Critique', in Elizabeth S. Anker \& Rita Felski (eds) Critique and Postcritique (Durham, NC, Duke University Press), 211-29.

https://doi.org/10.1215/9780822373049-009

Chamayou, Grégoire (2015), A Theory of the Drone, trans. Janet Lloyd (New York, The New Press).

Chandler, James (2004), 'Critical Disciplinarity', Critical Inquiry, 30(2): 355-60. https://doi.org/10.1086/421132

Chow, Rey (2006), The Age of the World Target: Self-referentiality in War, Theory, and Comparative Work (Durham, NC, Duke University Press), 1-43. https://doi.org/10.1215/9780822387589

Cusset, François (2008), French Theory: How Foucault, Derrida, Deleuze, \& Co. Transformed the Intellectual Life of the United States, trans. Jeff Fort (Minneapolis, MN, University of Minnesota Press).

Davis, Mike (2008), Buda's Wagon: A Brief History of the Car Bomb (London, Verso).

Dawes, James (2005), The Language of War: Literature and Culture in the U.S. from the Civil War through World War II (Cambridge, MA, Harvard University Press).

de Certeau, Michel (1984), The Practice of Everyday Life, trans. Steven Rendall (Berkeley, CA, University of California Press).

De Landa, Manuel (1991), War in the Age of Intelligent Machines (New York, Zone Books).

Deleuze, Gilles \& Guattari, Félix (1986), Nomadology: The War Machine, trans. Brian Massumi (New York, Semiotext(e)).

Denning, Michael (2004), Culture in the Age of Three Worlds (London, Verso). 
Der Derian, James (2009), Virtuous War: Mapping the Military-Industrial-Media-Entertainment Network (New York, Routledge). https://doi.org/10.4324/9780203881538

DeRosa, Aaron \& Peebles, Stacey (2017), 'Enduring Operations: Narratives of the Contemporary Wars', Modern Fiction Studies, 63(2): 203-24. https://doi.org/10.1353/mfs.2017.0019

Derrida, Jacques (1973), 'Différance', in Speech and Phenomena and Other Essays on Husserl's Theory of Signs, trans. David B. Allison (Evanston, IL, Northwestern University Press), 129-60.

Derrida, Jacques (1976), Of Grammatology, trans. Gayatri Chakravorty Spivak (Baltimore, MD, Johns Hopkins University Press).

Derrida, Jacques (1978), Writing and Difference, trans. Alan Bass (Chicago, IL, University of Chicago Press).

Derrida, Jacques (1982), 'White Mythology: Metaphor in the Text of Western Philosophy', in Margins of Philosophy, trans. Alan Bass (Chicago, IL, University of Chicago Press), 207-71.

Derrida, Jacques (1988), 'The Purveyor of Truth', trans. Alan Bass, in John P. Muller \& William J. Richardson (eds) The Purloined Poe: Lacan, Derrida, and Psychoanalytic Reading (Baltimore, MD, Johns Hopkins University Press),173-212.

Derrida, Jacques (1992), 'Force of Law: The "Mystical Foundation of Authority", trans. Mary Quaintance, in Drucilla Cornell, Michel Rosenfeld \& David Gray Carlson (eds) Deconstruction and the Possibility of Justice (New York, Routledge), 3-67.

Derrida, Jacques (1994), Specters of Marx: The State of the Debt, the Work of Mourning, and the New International, trans. Peggy Kamuf (New York, Routledge).

Dickstein, Morris (2004), 'Afterword: Historicism and its Limits', in Peter C. Herman (ed.) Historicizing Theory (Albany, NY, State University of New York Press), 301-14.

During, Simon (2017), 'The Eighteenth-century Origins of Critique', in Elizabeth S. Anker \& Rita Felski (eds) Critique and Postcritique (Durham, Duke University Press), 73-96. https://doi.org/10.1215/9780822373049-004

Felski, Rita (2015), The Limits of Critique (Chicago, IL, University of Chicago Press). https://doi.org/10.7208/chicago/9780226294179.001.0001

Foucault, Michel (1986), 'Society Must be Defended': Lectures at the College de France 1975-1976, trans. David Macey, edited by Mauro Bertani \& Alessandro Fontana (New York, Picador).

Foucault, Michel (2002), 'What is Critique?, in David Ingram (ed.) The Political (Malden, MA, Blackwell), 193-211.

Galtung, Johan (1969), 'Violence, Peace, and Peace Research', Journal of Peace Research, 6(3): 167-91. https://doi.org/10.1177/002234336900600301

Garver, Newton (1979), 'Preface', in Jacques Derrida, Speech and Phenomena, and Other Essays on Husserl's Theory of Signs (Evanston, IL, Northwestern University Press), ix-xxx.

Gat, Azar (2001), A History of Military Thought (Oxford, Oxford University Press).

Godzich, Wlad (1994), 'Literacy and the Struggle for Theory', in The Culture of Literacy (Cambridge, MA, Harvard University Press), 1-35.

Graff, Gerald (2007), Professing Literature: An Institutional History (Chicago, IL, University of Chicago Press). https://doi.org/10.7208/chicago/9780226305257.001.0001

Graham, Stephen (2009), 'The Urban "Battlespace", Theory, Culture, and Society, 26(7-8): 278-88. https://doi.org/10.1177/0263276409349280

Gray, Chris Hables (1997), Postmodern War: The New Politics of Conflict (New York, The Guilford Press).

Gregory, Derek (2011), 'The Everywhere War', The Geographical Journal, 177(3): 238-50. https://doi.org/10.1111/j.1475-4959.2011.00426.x

Guillory, John (2002), 'Literary Study and the Modern System of the Disciplines', in Amanda Anderson \& Joseph Valente (eds) Disciplinarity at the Fin de Siècle (Princeton, NJ, Princeton University Press), 19-43. 
Hardt, Michael \& Negri, Antonio (2004), Multitude: War and Democracy in the Age of Empire (New York, Penguin).

Harvey, Irene (1988), 'Structures of Exemplarity in Poe, Freud, Lacan, and Derrida', in John P. Muller \& William J. Richardson (eds) The Purloined Poe: Lacan, Derrida, and Psychoanalytic Reading (Baltimore, MD, Johns Hopkins University Press), 252-67.

Herman, Peter C. (2004), 'Introduction to Historicizing Theory', in Peter C. Herman (ed.) Historicizing Theory (Albany, NY, State University of New York Press), 1-16.

Hoy, David Couzens (2004), Critical Resistance: From Poststructuralism to Post-critique (Cambridge, MA, MIT Press). https://doi.org/10.7551/mitpress/2217.001.0001

Hunter, Ian (2006), 'The History of Theory', Critical Inquiry, 33(1): 78-112. https://doi.org/10.1086/509747

Hüppauf, Bernd (1997), 'Introduction. Modernity and Violence: Observations Concerning a Contradictory Relationship', in B. Hüppauf (ed.) War, Violence, and the Modern Condition (Berlin, Walter de Gruyter), 1-29. https://doi.org/10.1515/9783110817256.1

Jameson, Fredric (1984), 'Periodizing the 60s', Social Text, 9/10: 178-209. https://doi.org/10.2307/466541

Jameson, Fredric (1991), Postmodernism; or, The Cultural Logic of Late Capitalism (Durham, NC, Duke University Press). https://doi.org/10.1215/9780822378419

Jameson, Fredric (1999), 'Marx’s Purloined Letter', in Michael Sprinker (ed.) Ghostly Demarcations: A Symposium on Jacques Derrida's Specters of Marx (London, Verso), 26-67.

Jameson, Fredric (2004), 'Symptoms of Theory or Symptoms for Theory?', Critical Inquiry, 30(2): 403-8. https://doi.org/10.1086/421141

Jameson, Fredric (2008a), 'The Ideology of the Text', in The Ideologies of Theory (London, Verso), $20-76$.

Jameson, Fredric (2008b), 'How Not To Historicize Theory', in The Ideologies of Theory (London, Verso), 286-308.

Jameson, Fredric (2016), 'An American Utopia', in Slavoj Žižek (ed.) An American Utopia: Dual Power and the Universal Army (London, Verso), 1-96.

Joque, Justin (2018), Deconstruction Machines: Writing in the Age of Cyberwar (Minneapolis, MN, University of Minnesota Press). https://doi.org/10.5749/j.ctt20vxpw5

Keegan, John (1988), The Mask of Command (New York, Penguin).

Keegan, John \& Holmes, Richard (1986), Soldiers: A History of Men in Battle (New York, Viking).

Keenan, Thomas (1997), Fables of Responsibility: Aberrations and Predicaments in Ethics and Politics (Stanford, CA, Stanford University Press).

Koistinen, Paul (2004) Arsenal of World War II: The Political Economy of American Warfare, 1940-1945 (Lawrence, KS, University Press of Kansas).

Kosofsky Sedgwick, Eve (1997), 'Paranoid Reading and Reparative Reading; or, You're So Paranoid, You Probably Think This Introduction is About You', in Eve Kosofsky Sedgwick (ed.) Novel Gazing: Queer Readings in Fiction (Durham, NC, Duke University Press), 1-37. https://doi.org/10.1215/9780822382478-001

Latour, Bruno (2004), 'Why Has Critique Run Out of Steam? From Matters of Fact to Matters of Concern', Critical Inquiry, 30(2): 225-48. https://doi.org/10.1086/421123

Lentricchia, Frank (1980), After the New Criticism (Chicago, IL, University of Chicago Press). https://doi.org/10.7208/chicago/9780226229058.001.0001

Liddell Hart, Sir Basil Henry (1991), Strategy, 2nd revised edn (New York, Meridian); first published 1967. Lindqvist, Sven (2000), A History of Bombing, trans. Linda Haverty Rugg (New York, The New Press).

Love, Heather (2017), 'The Temptations: Donna Haraway, Feminist Objectivity, and the Problem of Critique', in Elizabeth S. Anker \& Rita Felski (eds) Critique and Postcritique (Durham, NC, Duke University Press), 50-72. 
Lyotard, Jean-François (1985), The Postmodern Condition: A Report on Knowledge, trans. Geoff Bennington \& Brian Massumi (Minneapolis, MN, University of Minnesota Press). https://doi.org/10.1215/9780822373049-003

McLellan, David (1970), Marx Before Marxism (New York, Harper \& Row).

McLellan, David (ed.) (2000), Karl Marx: Selected Writings, 2nd edn (Oxford, Oxford University Press). Moretti, Franco (1988), Signs Taken for Wonders: Essays in the Sociology of Literary Forms, trans. Susan Fischer, David Forgacs \& David Miller (London, Verso).

Newfield, Christopher (2008), Unmaking the Public University: The Forty-year Assault on the Middle Class (Cambridge, MA, Harvard University Press), 142-58.

Nixon, Rob (2011), Slow Violence and the Environmentalism of the Poor (Cambridge, MA, Harvard University Press). https://doi.org/10.4159/harvard.9780674061194

Partridge, Eric (1959), Origins: A Short Etymological Dictionary of Modern English (New York, Macmillan).

Paxson, James J. (2003), 'Historicizing Paul de Man's Master Trope Prosopopeia: Belgium's Trauma of 1940, the Nazi Volkskörper, and Versions of the Allegorical Body Politic', in Peter C. Herman (ed.) Historicizing Theory (Albany, NY, State University of New York Press), 69-97.

Raber, Karen (2004), 'Michel Foucault and the Specter of War', in Peter C. Herman (ed.) Historicizing Theory (Albany, NY, State University of New York Press), 49-67.

Rousset, Jean (1963) Forme et Signification (Paris, José Corti).

Shipley, Joseph T. (1984), The Origins of English Words: A Discursive Dictionary of Indo-European Roots (Baltimore, MD, The Johns Hopkins University Press).

Shumway, David R. (2004), 'The Sixties, the New Left, and the Emergence of Cultural Studies in the United States', in Peter C. Herman (ed.) Historicizing Theory (Albany, NY, State University of New York Press), 235-54.

Shy, John (1986), 'Jomini', in Peter Paret, Gordon Alexander Craig \& Felix Gilbert (eds) Makers of Modern Strategy: From Machiavelli to the Nuclear Age (Princeton, NJ, Princeton University Press), 143-85. https://doi.org/10.1515/9781400835461-008

Toscano, Alberto (2007), “"European nihilism” and beyond: commentary by Alberto Toscano', in Alain Badiou The Century trans. Alberto Toscano (Cambridge, Polity Press), 179-201.

Vagts, Alfred (1959), A History of Militarism: Civilian and Military, revised edn (New York, The Free Press).

Weber, Samuel (2005), Targets of Opportunity: On the Militarization of Thinking (New York, Fordham University Press).

To cite the article: Stephen Carter (2020), 'Texts and tactics: an indirect approach to violence', Journal of the British Academy, 8(s3): 111-132.

DOI https://doi.org/10.5871/jba/008s3.111

Journal of the British Academy (ISSN 2052-7217) is published by

The British Academy, 10-11 Carlton House Terrace, London, SW1Y 5AH

www.thebritishacademy.ac.uk 